Edited by Prof. Dr. Otto Kandler, München

1982. approx. 360 pp, 152 fig. and 50 tab., cloth, approx.

DM 98,-

Enlarged and completed reprint from "Zentralblatt für Bakteriologie, Mikrobiologie and Hygiene, Series C: General, Applied and Ecological Microbiology" Vol. 3 (1982) Nr. $1 / 2$ (Gustav Fischer Verlag Stuttgart, New York)

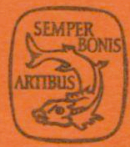

Gustav Fischer Verlag Stuttgart · New York
Archaebacteria

Proceedings of the First International

Workshop on Archaebacteria,

Munich June 27th-July 1st, 1981

Table of contents: General Aspects - RNA Structures . Genom Organisation and Phages - Proteinsynthesis . Cell Wall Structures - Ribosomal Proteins - RNA Polymerases - Lipids and Membranes - Coenymes - Metabolism

This is the first book dealing with all aspects of the "concept of the archaebacteria".

The concept of "archaebacteria" based on the sequence similarity of ribosomal 16 S (18S) RNA, has provided us with startling unexpected new insights into genealogical relationship between organisms and must be considered a break-through in the search for a natural system of bacteria, the final goal of bacterial systematics. In addition, the concept of the archaebacteria is exerting a marked stimulatory effect on molecular genetics, comparative biochemistry and physiology and has far-reaching implications for ecological and applied microbiology.

The main emphasis of these contributions is in the area of the molecular biological and biochemical aspects of archaebacteria. There are also papers on geochemistry, paleontology and systematics which have been included to give a complete picture.

This book provides the most complete and compact account of this new fast rising multidisciplinary research area. It is essential for any scientist, who wants to have profound and extensive information on this field. 
Zbl. Bakt. Hyg., I. Abt. Orig. C 3, 128-139 (1982)

Lehrstuhl für Mikrobiologie der Universität Regensburg, Regensburg, Federal Republic of Germany

\section{Histone-like Proteins in Eu- and Archaebacteria $\star$}

MICHAEL THOMM, KARL O. STETTER, and WOLFRAM ZILLIG ${ }^{1}$

Received July 27, 1981 


\section{Summary}

The DNA of 5 species of eubacteria and 5 species of archaebacteria was isolated by isopyknic centrifugation in metrizamide density gradients. It is associated with high amounts (protein: DNA $\approx 0.25 \mathrm{w} / \mathrm{w}$ ) of small, acid-soluble proteins with molecular weights ranging from 5,500 to 14,300. Electrophoreses of these proteins according to charge density showed that nearly all of them are very basic, some of the archaebacterial proteins even as basic as calf thymus histones.

Antibodies against the histone-like protein of Escherichia coli formed precipitates with extracts of 13 species of eubacteria, of which some were phylogenetically quite distant from Escherichia coli, but not with extracts from archaebacteria. Dodecylsulfate polyacrylamide gel electrophoresis of the precipitates yielded bands of identical molecular weights as those obtained after metrizamide centrifugation. No precipitation could be detected with extracts from archaebacteria or with calf thymus histones.

Antibodies against the histone-like protein of Thermoplasma reacted only with the corresponding extract, but not with those from other archaebacteria e.g. Sulfolobus, Thermoproteus, Methanobacterium, Methanococcus and Methanosarcina. They also did not yield precipitates with extracts of eubacteria and with calf thymus histones.

Key words: Archaebacteria - DNA - Eubacteria - Histone-like proteins - Nucleoprotein

\section{Introduction}

The nucleus of eukaryotes contains large amounts of basic proteins, the histones (Kossel, 1884). Since significant amounts of proteins were previously not found in association with prokaryotic DNA, it had been assumed that histone-like proteins do not exist in bacteria (Leaver and Cruft, 1966; Raat and Bonner, 1968; Bonner et al., 1968; Makino and Tsusuki, 1971; Hsiang and Cole, 1973).

* Paper given at the First International Workshop on Archaebacteria, München, June 27 to July 1, 1981.

1 Max-Planck-Institut für Biochemie, D-8033 Martinsried, Federal Republic of Germany. 
A prokaryotic small basic DNA-bound protein was first detected in large amounts in Thermoplasma acidophilum by Searcy (1975). As he could not find a similar protein in Escherichia coli, he suggested that the histone-like protein of Thermoplasma is an adaption of this thermophilic bacterium helping to stabilize the DNA in its extreme environment.

However, Varshavsky et al. (1977) found two histone-like proteins associated with the isolated DNA of Escherichia coli. The localization of one of them, the HU-protein, on the DNA of Escherichia coli could be confirmed by RouvièreYaniv (1978). A serologically cross-reacting protein was detected by Haselkorn and Rouvière-Yaniv (1976) in cyanobacteria.

In this paper we report on the distribution of histone-like proteins in various members of eu- and archaebacteria of different habitats. These proteins were identified by antibody precipitation and by isopyknic centrifugation in metrizamide density gradients, a method already applied to the isolation of eukaryotic chromatin (Birnie et al., 1973).

\section{Materials and Methods}

\section{Bacterial strains and growth conditions}

The origin, the source of the bacteria, and the culture conditions are summarized in Table 1.

All eubacteria with the exception of Thermus $s p$. were grown in HD-medium (pepton $5 \mathrm{~g} / \mathrm{l}$, yeast extract $2.5 \mathrm{~g} / \mathrm{l}$, glucose $1 \mathrm{~g} / \mathrm{l} ; \mathrm{pH} 7.0$ ) at $37^{\circ} \mathrm{C}$.

Thermus sp., Abano Terme, isolated by W. Zillig and K. O. Stetter was grown aerobically at $78^{\circ} \mathrm{C}$ and at $\mathrm{pH} 7.2$ (adjusted with $1 \mathrm{n} \mathrm{NaOH}$ ) in a medium containing per liter: $1.46 \mathrm{~g} \mathrm{NaCl}, 0.21 \mathrm{~g} \mathrm{NaHCO}_{3}, 0.20 \mathrm{~g} \mathrm{KHSO}_{4}, 0.37 \mathrm{~g} \mathrm{MgSO}_{4} \cdot 7 \mathrm{H}_{2} \mathrm{O}, 0.51 \mathrm{~g} \mathrm{KCl} \cdot$ $2 \mathrm{H}_{2} \mathrm{O}, 0.0132 \mathrm{~g}\left(\mathrm{NH}_{4}\right)_{2} \mathrm{SO}_{4}, 0.028 \mathrm{~g} \mathrm{FeSO}_{4} \cdot 7 \mathrm{H}_{2} \mathrm{O}$ and $2 \mathrm{~g}$ yeast extract (Difco). The cells were harvested by continuous centrifugation in a Padberg centrifuge type $61 \mathrm{G}$ and stored at $-80^{\circ} \mathrm{C}$.

\section{Isolation of the nucleoproteins}

Procedure A: The nucleoprotein of Thermoplasma acidophilum was isolated by the procedure of Searcy (1975) with the following slight modifications: the DNA was sheared with an Omni-mixer (Sorvall) for $2-3 \mathrm{~min}$ at $10,000 \mathrm{rev} . / \mathrm{min}$ and the concentrated ribosome-free supernatant was applied to a chromatography column $(97 \times 3 \mathrm{~cm})$ containing Biogel A $15 \mathrm{~m}, 50-100$ mesh (Bio Rad).

Procedure B: This method was generally used for the isolation of the nucleoproteins: $4 \mathrm{~g}$ of frozen cells were thawed in $20 \mathrm{ml}$ buffer A $(0.01 \mathrm{~mol} / 1 \mathrm{Tris}-\mathrm{HCl}, \mathrm{pH} \mathrm{7.4}, 0.2 \mathrm{~mol} / 1$ $\mathrm{NaCl}, 0.01 \mathrm{~mol} / \mathrm{l} \mathrm{MgCl}{ }_{2}$; Searcy, (1975)), and suspended employing a potter (Elvehjem) homogenizer with a loosely fitting pestle. The cells were lysed in a French Pressure Cell (34 ml, Aminco) at $88,600 \mathrm{kPa}$ and the crude extract was centrifuged at $50,000 \mathrm{rev} . / \mathrm{min}$ for 85 min at $5^{\circ} \mathrm{C}$ in a Beckman L 5-50 ultracentrifuge, rotor $50 \mathrm{Ti}$.

To $2-3 \mathrm{ml}$ of the clear supernatant a metrizamide stock-solution $(800 \mathrm{~g} / \mathrm{l}$ in buffer A) was added to a final metrizamide concentration of $520 \mathrm{~g} / \mathrm{l}$. Then a solution of ethidium bromide $(10 \mathrm{~g} / \mathrm{l})$ was added to a final concentration of $7 \mathrm{mg} / \mathrm{l}$ and the mixture was centrifuged for 96-104 $\mathrm{h}$ in polyallomer-tubes in the rotor $50 \mathrm{Ti}$ (Beckman L 5-50), at $45,000 \mathrm{rev} . / \mathrm{min}$ and $5^{\circ} \mathrm{C}$. After the run a sharp band was visible and could be isolated by suction with a syringe.

For a further purification, $1 \mathrm{ml}$ of DNA-fraction from the metrizamide gradient was mixed with $5 \mathrm{ml}$ metrizamide stock-solution, $7.5 \mathrm{ml}$ buffer $\mathrm{A}$ and $10 \mu \mathrm{l}$ ethidium bromide $(10 \mathrm{~g} / \mathrm{l})$ and centrifuged under the same conditions as described above. 
Table 1. Strains and culture conditions

\begin{tabular}{|c|c|c|c|}
\hline Strain & Designation & Origin & $\begin{array}{l}\text { Culture conditions } \\
\text { and references }\end{array}$ \\
\hline Escherichia coli $\mathrm{K} 12$ & M 1132 & Merck & HD-medium ae ${ }^{*}$ ) \\
\hline $\begin{array}{c}\text { Enterobacter } \\
\text { aerogenes }\end{array}$ & ATCC 13047 & ATCC & HD-medium ae \\
\hline Citrobacter sp. & ATCC 6750 & ATCC & HD-medium ae \\
\hline Proteus mirabilis & WS 100399 & WS & HD-medium ae \\
\hline $\begin{array}{l}\text { Pseudomonas } \\
\text { acidovorans }\end{array}$ & DSM 39 & DSM & HD-medium ae \\
\hline Pseudomonas putida & DSM 291 & DSM & HD-medium ae \\
\hline Thermus sp. & - & W.Zillig & Thermus medium \\
\hline $\begin{array}{l}\text { Staphylococcus } \\
\text { epidermidis }\end{array}$ & ATCC 12600 & ATCC & HD-medium ae \\
\hline Eubacterium limosum & DSM 20402 & N.Weiß & HD-medium an $* *)$ \\
\hline $\begin{array}{l}\text { Bacillus } \\
\quad \text { stearothermophilus }\end{array}$ & DSM 22 & B. Rexer & HD-medium ae \\
\hline Bacillus subtilis & DSM 10 & DSM & HD-medium ae \\
\hline Micrococcus luteus & DSM 20030 & DSM & HD-medium ae \\
\hline $\begin{array}{c}\text { Lactobacillus } \\
\text { bulgaricus }\end{array}$ & WS 6 & WS & De Man et al., 1960 \\
\hline $\begin{array}{l}\text { Lactobacillus } \\
\text { bavaricus }\end{array}$ & ATCC 31063 & K.O.Stetter & De Man et al., 1960 \\
\hline $\begin{array}{l}\text { Methanobacterium } \\
\text { thermoautotrophicum, } \\
\text { strain } \Delta \mathrm{H}\end{array}$ & DSM 1053 & R. Wolfe & Balch et al., 1979 \\
\hline $\begin{array}{l}\text { Methanococcus } \\
\text { vannielii, } \\
\text { strain SB }\end{array}$ & DSM 1224 & J. Winter & Balch et al., 1979 \\
\hline Methanosarcina barkeri & DSM 804 & H. Hippe & Balch et al., 1979 \\
\hline $\begin{array}{l}\text { Thermoplasma } \\
\text { acidophilum }\end{array}$ & ATCC 25905 & E. A.Freundt & Sturm et al., 1980 \\
\hline $\begin{array}{l}\text { Sulfolobus } \\
\text { solfataricus }\end{array}$ & DSM 1616 & W.Zillig & Zillig et al., 1980 \\
\hline $\begin{array}{l}\text { Sulfolobus } \\
\text { acidocaldarius }\end{array}$ & DSM 639 & DSM & Zillig et al., 1980 \\
\hline Sulfolobus brierleyi & DSM 1651 & $\begin{array}{l}\text { C.L. and J.A. } \\
\text { Brierley }\end{array}$ & Zillig et al., 1980 \\
\hline Thermoproteus tenax & DSM 2078 & W.Zillig & Zillig et al., 1981 \\
\hline
\end{tabular}

$\mathrm{M}=$ Merck, Darmstadt

ATCC = American Type Culture Collection, Rockville, USA

DSM = Deutsche Sammlung von Mikroorganismen, Göttingen

WS = Weihenstephan

${ }^{*}$ ) ae $=$ aerobically grown

*) an $=$ anaerobically grown

In the case of Methanobacterium thermoautotrophicum all solutions were gassed for one $h$ with $\mathrm{N}_{2}$ and contained $0.001 \mathrm{~mol} / 1$ 2-mercaptoethanol.

For preparation in large scale, portions $(38.5 \mathrm{ml})$ were centrifuged in polyallomer-tubes in the rotor $60 \mathrm{Ti}$ at $55,000 \mathrm{rev} . / \mathrm{min}$ for $72 \mathrm{~h}$ at $5{ }^{\circ} \mathrm{C}$. 


\section{Extraction of acid-soluble protein}

The nucleoprotein fraction was dialysed against distilled water (2-14 h) and diluted with 3 volumes of water. Then, the acid-soluble protein was extracted with $0.2 \mathrm{M}$ sulfuric acid (Searcy, 1975) and precipitated with ethanol at $-20^{\circ} \mathrm{C}$. The precipitate was dried in vacuo and dissolved in the required electrophoresis sample buffer (Laemmli, 1970 or Machicao and Sonnenbichler, 1971).

\section{Analytical procedures}

Electrophoretic procedures: Dodecylsulfate polyacrylamide gel electrophoresis was performed according to Laemmli (1970), but in 5-25\% exponential polyacrylamide gradient gels (Mirault and Scherrer, 1971).

Cellogel-electrophoresis was performed as described by Machicao and Sonnenbichler (1971).

Determination of DNA, RNA, and protein: 50-250 $\mu 1$ nucleoprotein fraction, isolated by metrizamide centrifugation, were diluted with water to a final volume of $1 \mathrm{ml}$. The ethidium bromide was removed with n-butanol at $0^{\circ} \mathrm{C}$. The nucleic acids were then precipitated with perchloric acid according to Rickwood et al. (1973). From the precipitate RNA and DNA were separated (Hutchinson and Munro, 1961) and then assayed by the orcinol and diphenylamine reaction (Burton, 1956), respectively.

Protein was determined by the micromethod of Heil and Zillig (1970).

\section{Preparation of antibodies}

A rabbit was immunized with a total of $250 \mu \mathrm{g}$ purified histone-like protein of Thermoplasma, another rabbit with $1 \mathrm{mg}$ of the histone-like protein of Escherichia coli using a micromethod described previously (Stetter, 1977). The $\gamma$-globulins were enriched from the serum by the method of Linn et al. (1973).

\section{Enrichment of heat-stable proteins for antibody precipitation}

The antibodies showed only precipitation with crude extracts of the corresponding bacterial strains, while in heterologous systems the histone-like proteins had to be enriched before by the following procedure:

$1 \mathrm{~g}$ cells were suspended in $1 \mathrm{ml}$ TAG buffer consisting of $0.05 \mathrm{M}$ Tris- $\mathrm{HCl}$ buffer $\mathrm{pH} 7.3$ containing $\mathrm{NH}_{4} \mathrm{Cl} 0.02 \mathrm{~mol} / \mathrm{l}, \mathrm{MgCl}_{2} 0.02 \mathrm{~mol} / \mathrm{l}$, and glycerol $100 \mathrm{~g} / \mathrm{l}$.

The cells were disrupted in an French pressure cell (Aminco) at 100,000 kPa. Pancreatic DNAase (Boehringer) was added at a final concentration of $20 \mathrm{mg} / \mathrm{l}$. After $1 \mathrm{~h} \mathrm{at} 37^{\circ} \mathrm{C}$ the suspension was diluted with $1 \mathrm{ml}$ buffer and then centrifuged at $45,000 \mathrm{rev} . / \mathrm{min}$ at $2{ }^{\circ} \mathrm{C}$ in the rotor $50 \mathrm{Ti}$. The clear supernatant was heated in a boiling water bath for $10 \mathrm{~min}$. The precipitate was removed by centrifugation $\left(10 \mathrm{~min} 21,000 \mathrm{rev} . / \mathrm{min}, 2^{\circ} \mathrm{C}\right.$, rotor JA 21, J 2-21 Beckman centrifuge) and the supernatant concentrated by precipitation with 4 vol. of ethanol $\left(1 \mathrm{~h}\right.$ at $\left.-20^{\circ} \mathrm{C}\right)$. The precipitated protein was collected by centrifugation $\left(20 \mathrm{~min}, 20,000 \mathrm{rev} . / \mathrm{min}\right.$, rotor JA 20 , at $\left.0^{\circ} \mathrm{C}\right)$, dried in vacuo and redissolved in 20-50 $\mu \mathrm{l}$ TAG buffer. For the investigation of thermophilic bacteria, the boilingstep was omitted, as no or very little precipitation occurred.

\section{Antibody precipitation}

For immunoprecipitation in solution, $20 \mu \mathrm{g}$ heat-stable protein fraction were combined with $10 \mu \mathrm{l}$ purified antiserum. This mixture was incubated for $16 \mathrm{~h}$ at $4{ }^{\circ} \mathrm{C}$.

\section{Preparation of immunoprecipitates for SDS polyacrylamide gel electrophoresis}

After the incubation the immunoprecipitate was collected by centrifugation $(15 \mathrm{~min}$, $21,000 \mathrm{rev} . / \mathrm{min}$, JA $21,2^{\circ} \mathrm{C}$ ), washed 2 times with $200 \mu \mathrm{l}$ TAG buffer containing 3 moles $/ \mathrm{l}$ $\mathrm{NH}_{4} \mathrm{Cl}, 2$ times with $50 \mu \mathrm{l}$ TAG, heated for $2 \mathrm{~min}$ at $95^{\circ} \mathrm{C}$ in $25 \mu \mathrm{l}$ sample buffer (Laemmli, 1970) and then loaded onto the polyacrylamide gel. 


\section{Results}

\section{Purification and composition of the bacterial nucleoprotein}

Isopyknic centrifugation of extracts containing bacterial DNAs in the presence of metrizamide yields sharp bands as visualised by ethidium bromide. These were further purified by repetition of the centrifugation. They contained in all cases, besides the DNA, large amounts of protein, which could not be removed from the DNA by repeated centrifugation. The protein/DNA ratios in the nucleoprotein complexes of Thermoplasma acidophilum, Sulfolobus acidocaldarius and Sulfolobus brierleyi (Table 3 ) are around $0.25(\mathrm{w} / \mathrm{w})$. For the nucleoproteins of other bacteria similar ratios were roughly estimated from relating the intensities of the stained protein bands in the polyacrylamide gels with the amounts of DNA, from which the proteins had been extracted.

No significant amounts of RNA could be detected in the purified nucleoprotein.

The DNA-binding proteins of Escherichia coli, Bacillus stearothermophilus, Lactobacillus bavaricus, Thermus sp., Thermoplasma acidophilum, Sulfolobus acidocaldarius, Sulfolobus solfataricus and Sulfolobus brierleyi are soluble in $0.2 \mathrm{M}$ sulfuric acid, while that of Methanobacterium thermoautotrophicum is not acidsoluble.

Table 2. Molecular weights of DNA-associated proteins of different eu- and archaebacteria determined from mobilities in SDS polyacrylamide gel electrophoresis*) (Fig. 1 and 2)

\begin{tabular}{lc}
\hline Organism & M. W. (daltons) \\
\hline Thermoplasma acidophilum & 9300 \\
Sulfolobus acidocaldarius & \\
component A & 9300 \\
component B & 6200 \\
Sulfolobus solfataricus & \\
component A & 9300 \\
component B & 5800 \\
Sulfolobus brierleyi & \\
component A & 12200 \\
component B & 10600 \\
component C & 9300 \\
component D & 7100 \\
component E & 5500 \\
Methanobacterium thermoautotrophicum & 14300 \\
Thermus sp. & 9300 \\
Bacillus stearothermophilus & 8100 \\
Lactobacillus bavaricus & \\
component A & 12000 \\
component B & 7400 \\
Escherichia coli K 12 & $7000 *$ )
\end{tabular}

* The calf thymus histones H3, H2A, H4 (Sonnenbichler and Zetl, 1975) and the histonelike protein of Escherichia coli (Rouvière-Yaniv and Gros, 1975) were used as standards. * calculated by Rouvière-Yaniv and Gros (1975) from the amino acid composition. 
Table 3. Ratio of acid-soluble protein/DNA in the nucleoprotein of different organisms

\begin{tabular}{ll}
\hline Organism & acid-soluble protein/DNA* \\
\hline Prokaryotes & \\
Sulfolobus acidocaldarius & 0.26 \\
Sulfolobus brierleyi & 0.25 \\
Thermoplasma acidophilum & 0.25 (Searcy, 1975) \\
& 0.36 \\
Escherichia coli & 0.12 (Rouvière-Yaniv, 1978) \\
Anabaena sp. & 0.14 (Haselkorn and Rouvière-Yaniv, 1976) \\
Eukaryotes & 0.25 (Hsiang and Cole, 1973) \\
Neurospora crassa & 1.0 (Marushige and Bonner, 1966) \\
Rat liver &
\end{tabular}

* w/w

Characterization of the bacterial DNA-associated proteins by SDS polyacrylamide gel electrophoresis

SDS polyacrylamide gel electrophoresis of the isolated nucleoprotein complexes yielded 1 to 5 bands with molecular weights ranging from 5500 to 14300 (Fig. 1 and 2, Table 2).

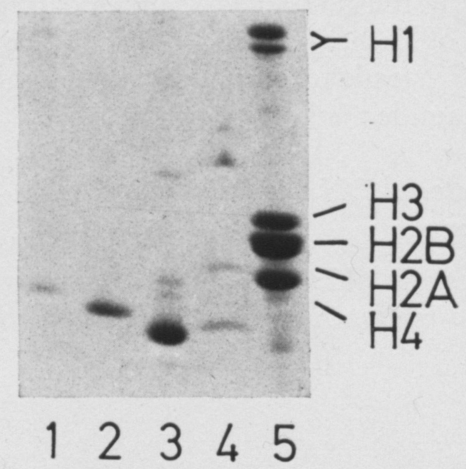

Fig. 1. Sodium dodecyl sulfate polyacrylamide gel electrophoresis of the DNA-associated proteins of different eubacteria. $1=$ Thermus sp.; 2 = Bacillus stearothermophilus; $3=$ Escherichia coli; $4=$ Lactobacillus bavaricus; $5=$ calf thymus histones.

In the case of Bacillus stearothermophilus the nucleoprotein was isolated with and without the proteinase-inhibitor phenyl-methylsulphonylfluoride (Sigma). No difference in the molecular weight of the polypeptide chain could be observed, however (not shown).

The nucleoproteins of Lactobacillus bavaricus (Fig. 1, lane 4) Sulfolobus acidocaldarius (Fig. 2, lane 3) and Sulfolobus solfataricus (Fig. 2, lane 4) contain 2 protein components, while that of Sulfolobus brierleyi (Fig. 2, lane 5) contains 5 . The DNA of Escherichia coli (Fig. 1, lane 3), Bacillus stearothermophilus (Fig. 1, lane 2), Thermus sp. (Fig. 1, lane 1) and Thermoplasma acidophilum (Fig. 2, lane 2), however, is associated with only one protein component. 


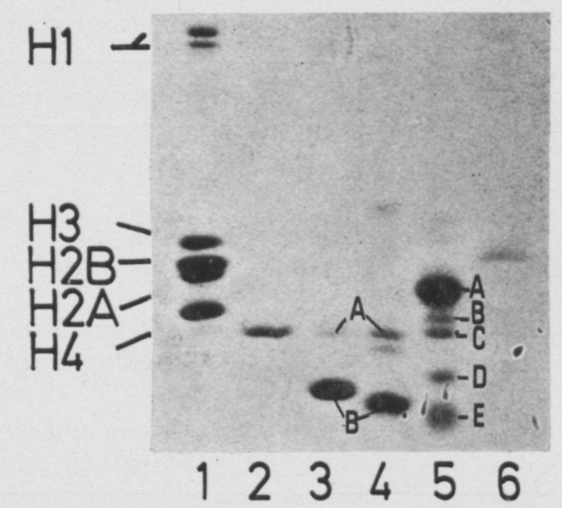

Fig. 2. Sodium dodecyl sulfate polyacrylamide gel electrophoresis of the histone-like proteins of archaebacteria. 1 = calf thymus histones; 2 = Thermoplasma acidophilum; $3=$ Sulfolobus acidocaldarius; $4=$ Sulfolobus solfataricus; $5=$ Sulfolobus brierleyi; $6=$ Methanobacterium thermoautotrophicum.

The isolation of the "histone-like" protein of Thermoplasma by the method of Searcy (1975) yielded a polypeptide (Fig. 3, lane 5) with the same electrophoretic mobility as that isolated by the metrizamide method (Fig. 3, lane 2-4). The isolation of the HU-protein of Escherichia coli by a method similar to that of Rouvière-Yaniv and Gros (1975) leads to a single protein comigrating in SDS gels with that isolated by the metrizamide method (not shown).

Characterization of bacterial DNA-associated proteins according to charge densities (cellogel electrophoresis)

In cellogel electrophoresis at $\mathrm{pH} 10$, the DNA-associated proteins of Sulfolobus acidocaldarius, Sulfolobus solfataricus, Sulfolobus brierleyi and Thermoplasma

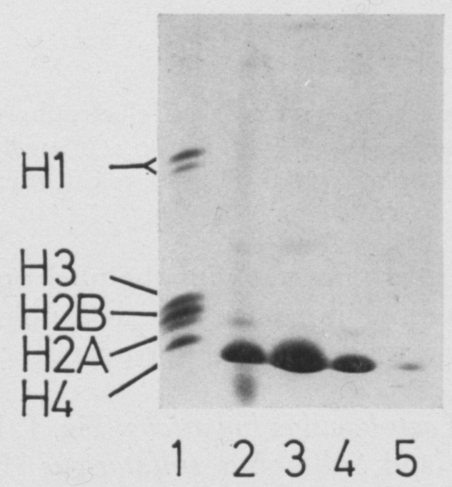

Fig. 3. Sodium dodecyl sulfate polyacrylamide gel electrophoresis of DNA-binding proteins of Thermoplasma acidophilum. $1=$ calf thymus histones; $2,3,4=$ protein extracted from nucleoprotein fractions purified by metrizamide centrifugation; $5=$ acid soluble protein extracted from the nucleoprotein purified by column-chromatography. 


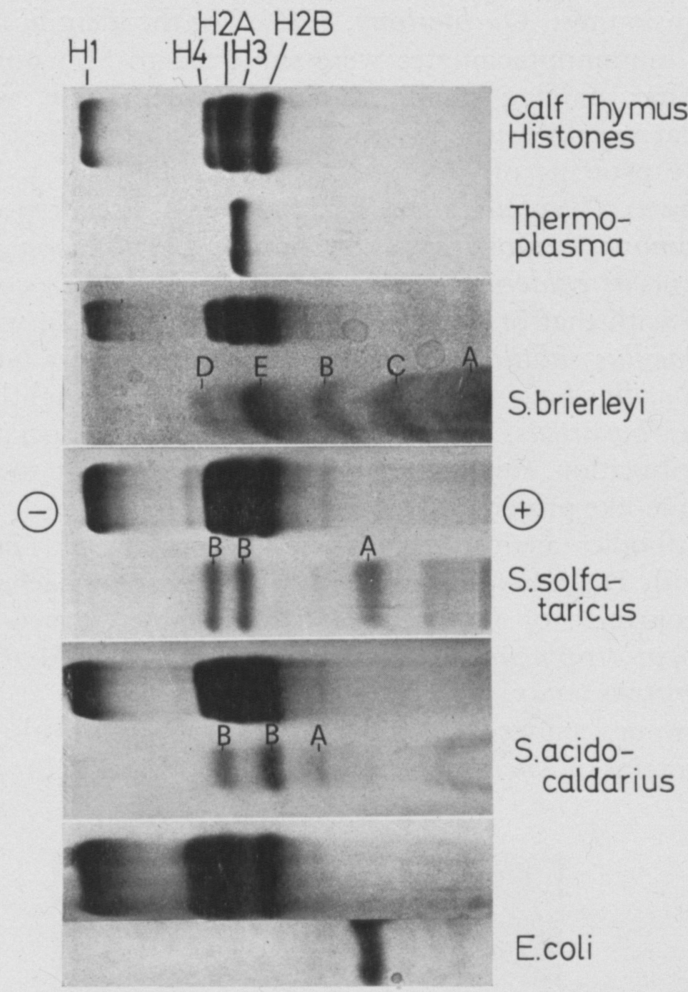

Fig. 4. Cellogel electrophoresis of calf thymus histones and bacterial histone-like proteins of different origin. The numbering of the bands refers to the corresponding positions in the SDS polyacrylamide gel (Fig. 2).

acidophilum migrate to the cathode similar to calf thymus histones (Machiaco and Sonnenbichler, 1971), (Fig. 4), indicating a similar basicity.

In the preparations of Escherichia coli and Thermoplasma, only one band could be detected (Fig. 4). The protein of Escherichia coli is less basic than that of Thermoplasma and than calf thymus histones. Each of the different Sulfolobus species, however, yields several bands in the cellogel electrophoresis (Fig. 4), differing significantly in charge densities, 5 in Sulfolobus brierleyi and 3 each in $S$. acidocaldarius and $S$. solfataricus. After cellogel electrophoresis, the bands were identified and eluted as described by Heil and Zillig (1970) and the molecular weights were determined by SDS polyacrylamide gel electrophoresis. The two most basic bands of Sulfolobus acidocaldarius (Fig. 4) and Sulfolobus solfataricus (Fig. 4), respectively, migrate to the same position in polyacrylamide gels (Fig. 2, lanes 3 and 4), indicating an identical molecular weight.

\section{Serology}

The heat-stable protein fractions of 11 eubacteria yielded precipitation lines (not shown) with an antibody against the histone-like protein of Escherichia coli 
in the immunodiffusion test (Ouchterlony, 1960). For the identification of the cross reacting proteins, immunoprecipitates were subjected to SDS polyacrylamide gel electrophoresis. After staining small proteins became visible, which were very similar in molecular weight to the histone-like protein of Escherichia coli (Fig. 5).

The histone-like proteins of Enterobacter aerogenes (Fig. 5, lane 4), Proteus mirabilis (not shown), Citrobacter sp. (Fig. 5, lane 3), Pseudomonas putida (Fig. 5, lane 5), Pseudomonas acidovorans (not shown), Eubacterium limosum (Fig. 5, lane 7), Staphylococcus epidermidis (Fig. 5, lane 8), and Micrococcus luteus (not shown) comigrate with that of Escherichia coli (Fig. 5, lane 2), while the histonelike proteins of Bacillus subtilis (Fig. 5, lane 6), Lactobacillus bulgaricus (Fig. 5, lane 9) and Lactobacillus bavaricus (Fig. 5, lane 10) migrate slightly slower.

In Lactobacillus bavaricus, which yielded two DNA-associated proteins by metrizamide centrifugation, only the smaller one turned out to be serologically related to the histone-like protein of Escherichia coli.

In contrast, antibodies against the histone-like protein of Thermoplasma did not cross react with DNA-binding proteins from other archaebacteria including the purified nucleoprotein of Sulfolobus and heat-stable extracts from Methanobacterium thermoautotrophicum, Methanococcus vannielii, Methanosarcina barkeri and Thermoproteus tenax.

Calf thymus histones showed no precipitation line both with the sera against the histone-like proteins of Thermoplasma and Escherichia coli.

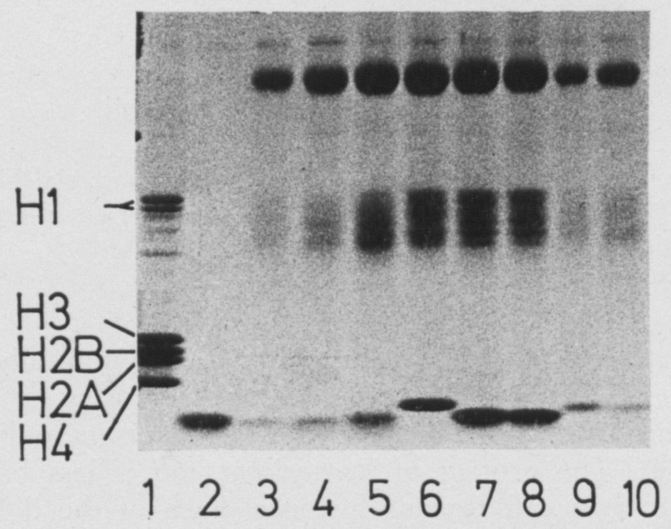

Fig. 5. Sodium dodecyl sulfate polyacrylamide gel electrophoresis of immunoprecipitates formed by antibody precipitation with an antiserum against the histone-like protein of Escherichia coli and extracts of different eubacteria. $1=$ calf thymus histones; $2=$ histone-like protein of Escherichia coli; 3-10 = immunoprecipitates of: (3) Citrobacter sp.; (4) Enterobacter aerogenes; (5) Pseudomonas acidovorans; (6) Bacillus subtilis; (7) Eubacterium limosum; (8) Staphylococcus epidermidis; (9) Lactobacillus bulgaricus; (10) Lactobacillus bavaricus.

\section{Discussion}

The existence of the histone-like protein bound to the DNA of Thermoplasma (Searcy, 1975) could be confirmed by metrizamide density gradient centrifuga- 
tion. In Escherichia coli, only one of the two DNA-binding proteins described by Varshavsky et al. (1977) was found by the metrizamide method. This protein migrates to the same position in SDS polyacrylamide gels as the Escherichia coli DNA-binding protein HU described by Rouvière-Yaniv and Gros (1975) and therefore appears to be identical with it. The second protein found in Escherichia coli by Varshavsky et al. (1977) possibly binds only to the DNA at the very low ionic strength used by these authors.

Histone-like proteins are thus not restricted to thermophiles, as previously supposed by Searcy (1975). On the contrary, they appear to be bound to the DNAs of all members of both prokaryotic kingdoms, the eubacteria and the archaebacteria.

In eubacteria, the histone-like proteins appear to be very conservative in structure as already known for eukaryotic histones: Even proteins of bacteria phylogenetically far distant from Escherichia coli, e. g. Micrococcus, Lactobacillus and Eubacterium show precipitation with the antibodies against the HU-protein of Escherichia coli. Besides their serological relationship, these proteins are also very similar in their molecular weights. In analogy to histones they are heatstable and soluble in dilute mineral acids, indicating a strong basicity. Although these features fit also to eukaryotic histones, no serological cross reaction between the latter and the histone-like protein of Escherichia coli was observed.

In archaebacteria, the histone-like proteins are usually as basic as eukaryotic histones (exception: Methanobacterium thermoautotrophicum). Although they were found in all species inspected, no serological cross reaction with antibodies against the Thermoplasma-protein could be observed, possibly because of a higher phylogenetic diversity of the archaebacteria or a less conservative structure of these proteins.

The function of the histone-like proteins remains still unclear. As they are present on the DNA in as high amounts as histones in lower eukaryotes (Table 3), they may play a similar role, possibly in the formation of a quarternary structure (Rouvière-Yaniv et al., 1979) of the "chromatin" in prokaryotes.

\section{Acknowledgements}

We wish to thank Dr. I. Grummt for stimulating discussions and Dr. J. Sonnenbichler for the generous gift of calf thymus histones. Thanks are also due to P. Frischeisen for excellent assistance. This work was supported by a grant of the Deutsche Forschungsgemeinschaft to K. O. Stetter.

\section{References}

Balch, W. E., Fox, G. E., Magrum, L. J., Woese, C. R., Wolfe, R. S.: Methanogens: Reevaluation of a unique biological group. Microbiol. Rev. 43, 260-296 (1979)

Birnie, G. D., Rickwood, D., Hell, A.: Buoyant densities and hydration of nucleic acids, proteins and nucleoprotein complexes in metrizamide. Biochim. Biophys. Acta 331, 283-294 (1973)

Bonner, J., Dahmus, M. E., Fambrough, D., Huang, R. C., Marushige, K., Tuan, D.: The biology of isolated chromatin. Science 159, 47-56 (1968) 
Burton, K.: A study of the conditions and mechanism of diphenylamine reaction for the colorimetric estimation of deoxyribonucleic acid. Biochem. J. 62, 315-322 (1956)

Haselkorn, R., Rouvière-Yaniv, J.: Cyanobacterial DNA-binding protein related to Escherichia coli HU. Proc. nat. Acad. Sci. (Wash.) 73, 1917-1920 (1976)

Heil, A., Zillig, W.: Reconstitution of bacterial DNA-dependent RNA polymerase from isolated subunits as a tool for the elucidation of the role of the subunits in transcription. FEBS Lett. 11, 165-168 (1970)

Hsiang, M. W., Cole, R. D.: The isolation of histones from Neurospora crassa. J. Biol. Chem. 248, 2007-2013 (1973)

Hutchinson, W. C., Munro, H. N.: The determination of nucleic acids in biological materials. Analyst $86,768-813$ (1961)

Kossel, A.: Úber einen peptonartigen Bestandtheil des Zellkerns. Z. physiol. Chem. 8, 511-515 (1884)

Laemmli, U. K.: Cleavage of structural proteins during the assembly of the head of the bacteriophage T 4. Nature (Lond.) 227, 680-685 (1970)

Leaver, J. L., Cruft, H. J.: Investigation into the distribution and properties of histones and other basic proteins in bacteria. Biochem. J. 101, 665-673 (1966)

Linn, T. G., Greenleat, A. L., Shorenstein, R. G., Losick, R.: Loss of the sigma activity of RNA polymerase of Bacillus subtilis during sporulation. Proc. nat. Acad. Sci. (Wash.) 70, 1865-1869 (1973)

Machicao, F., Sonnenbichler, J.: Cellogel electrophoresis of histones. Biochim. Biophys. Acta 236, 360-361 (1971)

Makino, F., Tsusuki, J.: Absence of histone in the blue-green alga Anabaena cylindrica. Nature (Lond.) 231, 446-447 (1971)

Man, J. C. de, Rogosa, M., Sharpe, M. E.: A medium for the cultivation of Lactobacilli. J. appl. Bact. 23, 130-135 (1960)

Marushige, K., Bonner, J.: Template properties of liver chromatin. J. molec. Biol. 15, 160-174 (1966)

Mirault, M. E., Scherrer, K.: Isolation of preribosomes from Hela cells and their characterisation by electrophoresis on uniform and exponential-gradient-polyacrylamide gels. Europ. J. Biochem. 23, 372-386 (1971)

Ouchterlony, O.: Diffusion-in-gel methods for immunological analysis II. In: Progress in allergy, Vol.. VT, pp. 30-154, (P. Kallod and B. H. Waksman, eds.). Basel, Karger 1962

Raaf, J., Bonner, J.: Properties of Escherichia coli deoxyribonucleoprotein as compared with the deoxyribonucleoprotein of higher organisms. Arch. Biochem. Biophys. 125, 567-579 (1968)

Rickwood, D., Hell, A., Birnie, G. D.: Isopycnic centrifugation of sheared chromatin in metrizamide gradients. FEBS Lett. 33, 221-224 (1973)

Rouvière-Yaniv, J., Gros, F.: Characterisation of a novel, low-molecular-weight DNAbinding protein from Escherichia coli. Proc. nat. Acad. Sci. (Wash.) 72, 3428-3432 (1975)

Rouvière-Yaniv, J.: Localisation of the HU-protein in the Escherichia coli nucleoid. Cold Spring Harbor Symp. Quant. Biol. 42, 439-447 (1978)

Rouviere-Yaniv, J., Yaniv, M., Germond, J.: E. coli DNA binding protein HU forms nucleosomelike structure with circular double-stranded DNA. Cell 17, 265-274 (1979)

Searcy, D. G.: Histone-like protein in the prokaryote Thermoplasma acidophilum. Biochim. Biophys. Acta 395, 535-547 (1975)

Sonnenbichler, J., Zetl, I.: The quantitative protein composition of calf thymus chromatin. Hoppe-Seyler's Z. physiol. Chem. 356, 599-603 (1975)

Stetter, K. O.: Transcription in Lactobacillaceae: DNA-dependent RNA polymerase from Lactobacillus casei. Isolation of transcription factor y. Hoppe-Seyler's Z. physiol. Chem. 358, 1093-1104 (1977)

Sturm, S., Schönefeld, U., Zillig, W., Janécovic, D., Stetter, K. O.: Structure and function 
of the DNA dependent RNA polymerase of the archaebacterium Thermoplasma acidophilum. Zbl. Bakt. Hyg., I. Abt. Orig. C 1, 12-25 (1980)

Varshavsky, A. J., Nedopasov, S. A., Bakayev, V. V., Bakayeva, T. G., Georgiev, G. P.: Histone-like protein in the purified E. coli deoxyribonucleoprotein. Nucleic Acid Res. 4, 2725-2745 (1977)

Zillig, W., Stetter, K. O., Wunderl, S., Schulz, W., Priess, H., Scholz, J.: The Sulfolobus"Caldariella" group: Taxonomy on the basis of the structure of DNA-dependent RNA polymerase. Arch. Microbiol. 125, 259-269 (1980)

Zillig, W., Stetter, K. O., Schäfer, W., Janécovic, D., Wunderl, S., Holz, I., Palm, P.: Thermoproteus: Two types of extremely thermoacidophilic anaerobians isolated from icelandic solfataras represent a novel group of Archaebacteria. Zbl. Bakt. Hyg., I. Abt. Orig. C 2, 205-227 (1981)

Prof. Dr. K. O. Stetter, Lehrstuhl für Mikrobiologie der Universität Regensburg, Universitätsstr. 31, D-8400 Regensburg, Fed. Rep. of Germany 